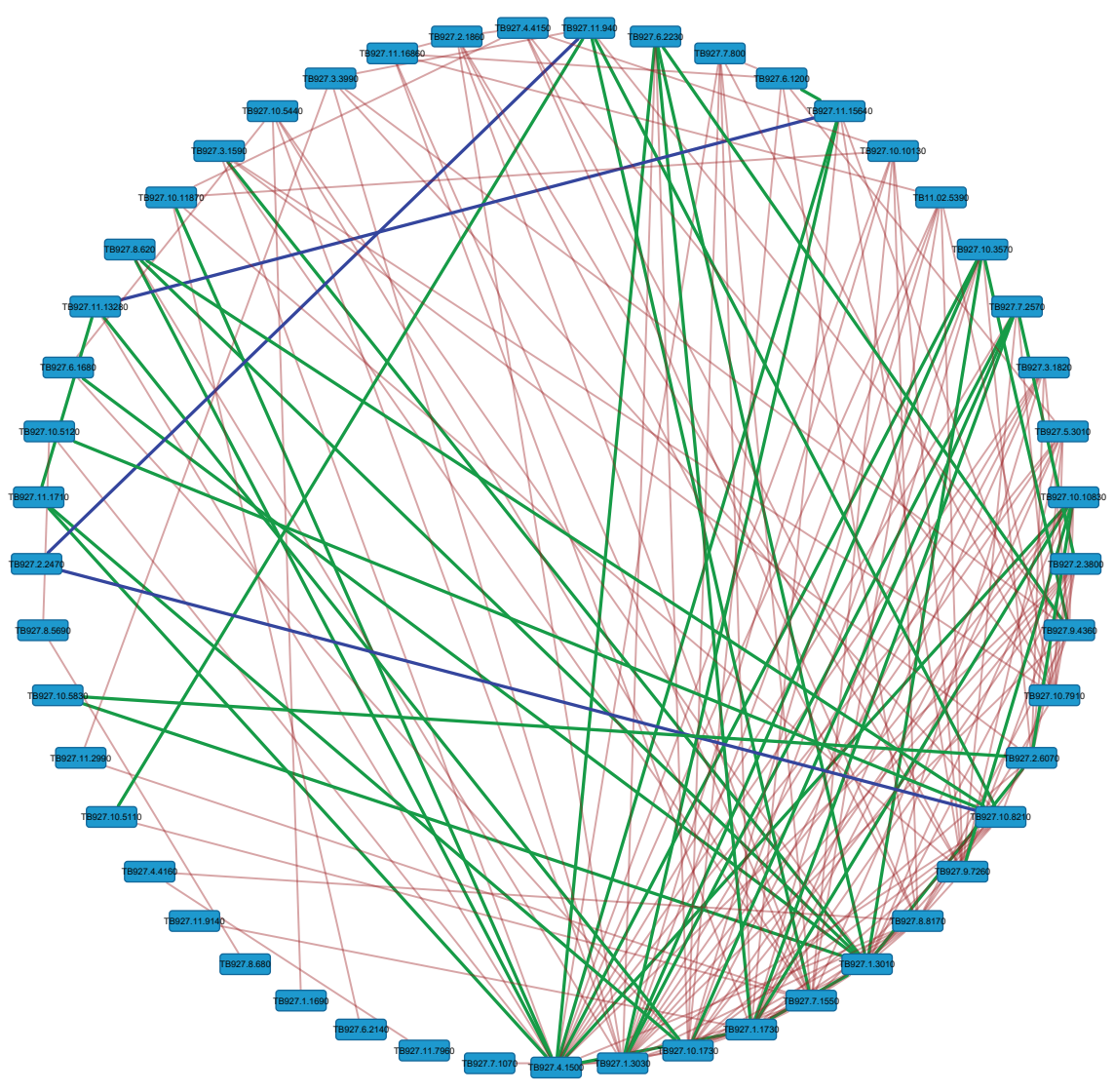

\title{
Edge colors
}

Reproducible

Identified by GG Identified by IEX 